\title{
A Suggested Web-Mediated Process Genre -Based Program for Developing Writing Autonomy of EFL Prospective Teachers
}

\author{
Eman Mohammed Abdel-Haq ${ }^{1}$, Hussein Taha Atta ${ }^{2}$, Abeer Ahmed Hammad Ali ${ }^{3}$ \\ ${ }^{1}$ Faculty of Education, Benha University, Egypt \\ ${ }^{2,3}$ Faculty of Education, Sohag University, Egypt \\ DOI:
}

\begin{abstract}
The aim of this study is to investigate the effect of a web-mediated program based on the combination of the process approach and the genre approach on developing writing autonomy among prospective teachers at Sohag Faculty of Education. Participants of the present study consisted of forty-six students who were chosen randomly from third- year students enrolled in English section at Faculty of Education, Sohag University, Egypt. The design of the study is the two-group post-assessment design, $(\mathrm{N}=23)$ for the experimental group and $(\mathrm{N}=23)$ for the control group. Both groups were tested before and after the intervention. The instruments of the research included a writing autonomy scale (WAS) and the suggested web-mediated process genre (WMPG) -based program. Results of the research revealed a statistically significant difference between the mean score of the experimental group and that of the control group in the post test of WAS in favor of the experimental group. These results were ascribed to using a program based on the combination of the process approach and the genre approach via the facilities of the
\end{abstract} Internet.

\section{Introduction}

Autonomous learners are reflective as they constantly rethink their ideas. Hence, they are accustomed to the customary of planning, monitoring and evaluating in everyday classroom work, ending in a more successful learning because learners are said to be more alert (Little, 2000). More importantly, these potent skills are then channeled into the real practice in their adulthood. Learners need to be autonomous as becoming one has lasting invaluable outcomes. It is an attribute that equips learners with life-long skills to enable the learner to function as a responsible independent learner in the short run and as an involved member of the society in the long run. This is in line with the country's aspiration in its journey to become a developed nation by the year 2020 .

In language settings, learner autonomy is believed to enhance language acquisition 
(Benson, 2006). In writing, learner autonomy is observed to be crucial as learners are 'given control over composing skills' (Hyland \& Hyland, 2006, p.33). In other words, learners are able to shape their essays without the abstaining pressure from any parties where they have the power to determine the content and rhetoric of their writing in the process of meaning-making. This will ensure the sustenance of essay ownership and resolution to 'text appropriation' (Hyland, 2000, p.34) issue that frequently occurs in teacher-centered learning environment. Critical and creative essay writings are the potential outcomes when one is given autonomy. Language settings, learner autonomy is believed to enhance language acquisition (Ahmad, Yaakub, Megat Abdul Rahim, 2004)

In writing, learner autonomy is observed to be crucial as learners are 'given control over composing skills' (Hyland \& Hyland, 2006, p.33). In other words, learners are able to shape their essays without the abstaining pressure from any parties where they have the power to determine the content and rhetoric of their writing in the process of meaning-making. This will ensure the sustenance of essay ownership and resolution to 'text appropriation' (Hyland, 2000, p.34) issue that frequently occurs in teacher-centered learning environment. Critical and creative essay writings are the potential outcomes when one is given autonomy.
For activating the communicative role of writing, EFL learners should write both in EFL class room, as a mark of their academic success, and beyond class as a response for actual demands; at the workplace, social media posts, etc. If the EFL learner cannot apply the knowledge of genres acquired in the classroom to real life context, the teaching procedure as well as the approach should be put to question. Learner autonomy is a learning construct that consolidates engaging EFL learners in meaningful tasks for the purpose of genuine communication.

According to Benson (2009), learner autonomy has been claimed to be an ultimate goal of education for a long time. Language teaching nowadays is seen not as an ability to teach but as an ability to make learners learn. Learner autonomy, as a construct for EFL learning success, has been recommended and confirmed in vivid pertinent studies (Sakai, Takagi \& Chu, 2010; Hadi, 2012; Ikonen, 2013; Yuliani, 2017).

As EFL writing is a cognitive thinking process that demands focused learning and an extended amount of time to generate ideas, plan, write, rewrite, and revise, learner autonomy should be developed in aligned with the development of EFL learners' writing skills. This claim was stated by Ahmad et al (cited in Hasim, Lumpur \& Zakaria (2016)" maintaining that "learner 
autonomy and writing are closely interrelated with one another and one way to encourage learner autonomy in writing is through Process Writing Approach where learning is learnercentered"(p.3). The result of investigations held by Bazrafkan and Bagheri (2015) and Masits (2016) showed that there is a significant and positive correlation between the autonomous learning, critical thinking skills, and writing proficiency of the learners across cognitive styles.

Reviewing pertinent studies, it can be concluded that some of them explored learner autonomy as an independent construct to develop writing performance of EFL learners (Yan,2007; Bagheri\&Aeen,2011), while others investigated the effect of writing programs aligned with writing approaches to develop EFL learner's autonomy in writing. For example, Yeung (2016) found that motivation, selfconfidence, independence from the teacher, and autonomous skills embracing strategy use and meta cognitive knowledge have a great effect on writing performance. Carr (2013) demonstrated that appealing to a variety of learning styles in foreign language writing instruction in English for Academic Purposes (EAP) setting may help students more effectively channel their efforts and develop learner autonomy. Similar conclusions have been drawn by Kulsirisawad (2012), Chiu (2012), and Nguyen (2016).
The development of web-mediated facilities in EFL instruction provides the practical means whereby learners can take a more active part in determining their own objectives and syllabi, as well as the path and timing they choose. Consequently, a change in the traditional roles could be brought out whereby the teacher is in tight control in the transmission of curricular content. It also increases the teachers' capacity to facilitate the task of helping learners become more independent and autonomous. Research has already confirmed that with highly advantages of web-based writing instruction with all its facilities in EFL instruction, learner autonomy can be developed (Kaur \& Sidhu, 2010; Eneau \& Develotte, 2012; Foroutan, Noordin \& bin Hamzah, 2013; Fuchs, Hauck, Müller-Hartmann,2013; Abdullah, 2015).

Process-genre approach (PGA) helps teachers shift responsibility gradually to their students once they get familiar with the different processes of composing needed to produce a text meeting the requirements of a particular genre. Consequently, it is clear that a synthesis between process-based approach and genrebased approach model is required to best facilitate the teaching of writing in order to ensure the highest possible written products. When implementing PGA, teachers should be aware of the following three general guidelines: As writing is so difficult, the teacher should 
adopt the role of assistant and guide and work closely with students to encourage them and offer helpful feedback and suggestions. It is crucial for teachers to offer positive and constructive advice on what students have written. Teachers also can make efforts to arouse curiosity and self-confidence by matching student interests to the writing topic and they should be sensitive to any individual differences that arise in the writing process.

Teachers should directly train students about writing strategies. If teachers demonstrate how prewriting activates the schemata and outline strategies for the drafting and revision processes, students will be more successful in writing compositions. Teachers should include the listening, speaking, and reading skills in the writing class. Integrating the four language skills promotes the expansion of the students' overall language competence. PGA makes this feasible, as background material is read during prewriting activities, and speaking and listening occur during lectures and when giving or receiving feedback (Yan, 2005).

Advocating web-based autonomous learning, knowledge could not be restricted to one source. Instead, it is multi-sources by which the emphasis is then shifted from just acquiring knowledge to reflecting upon it and taking control of choosing the most appropriate amount of it. Having access to the suggested web- mediated PG based- program that utilized in the present study, each student could actively participate in interacting with each stage of PG according to his/her own time of starting as teaching had the form of asynchronous communication. One issue of writing is being proposed; however, each member reflects upon it differently.

\section{Context of the problem}

Writing is one of the most complex activities that people can accomplish (Belkhir and Benyelles, 2017). It is undeniable that the hardest skill in English learning is writing which require learner's competency to receipt the information, process it, and at least, produce it. Seriously, learning writing is inadequate if only rely on the two hours or four hoursl learning in the classroom. Writing is about the long processes, which require more time, more effort, as well as more guidance.

Considering the cognitive processes of writing and the long time for focused concentration, the researchers conducted an interview with some EFL majors at the third -year at Sohag Faculty of Education in an effort to explore their knowledge of some linguistic structures of certain genres, to what extent they followed recursive process of writing, whether web-based facilities are integrated in their EFL writing class, and finally are their autonomous skills 
were taken into consideration before, during, and after writing. Results indicated that thirdyear EFL majors have limited class experiences in the stages of writing the different genres.

All the concern of writing instruction was upon error-free products of student writings, so the how of writing experiences were limited. Actually, third-year EFL majors did not practice web-based instruction synchronously or asynchronously. Few lecturers guided them to some writing links. They depend completely on their teachers to revise their writings and explaining the linguistic requirements of certain genres. Self-revising or genre analysis techniques are not questioned in their actual writing instruction.

Accordingly, it seems so imperative to find new approaches of teaching writing which embrace the potential of technology whereby students can be provided with ample scaffolds (reading models, interactive essay maps, joint writing activities, peer response, revising checklists, discussion forums, and organized asynchronous feedback). A web-mediated PGbased program is suggested, in the present study, to develop writing autonomy of EFL majors at Sohag Faculty of Education.

\section{Statement of the Problem}

The present EFL essay writing course, at Sohag Faculty of Education - English
Department, would not satisfy the requirements of the writing skills in certain genres. In addition, EFL majors were not trained to be autonomous learners. So, they depend on their teachers in selecting writing genres, revising their writings, and even analyzing the reading models. Thus, the advantages of life-long learning and student-centered instruction are not obvious in the actual writing practices within EFL college class. Consequently, the present study is an attempt to test an integrated PGA to develop the writing autonomy of third-year EFL majors of demanded written genres via an intended designed website with its valuable facilities.

\section{Questions of the study}

The present study attempted to answer the following questions:

1. What is the effect of the suggested on developing the writing autonomy of thirdyear EFL majors?

2. What are the features of the Web-Mediated PG-Based Program (WMPGP)?

\section{Hypothesis of the study}

The current study tests the following hypothesis:

- There is a statistically significant difference between mean scores of the experimental group students and the control group ones in 
the post-test of their writing autonomy scale in favor of the experimental group.

\section{Definition of Terms}

\section{Writing Autonomy:}

Learner autonomy was defined by Benson (2009) as " the ability to make the learners able to take control over their own learning to be successful not just in class, but also to learn independently without a teacher outside the class " (p.16).

Learner autonomy is basically viewed as a self-directed process of learning. Holec (as cited in Boyadzhieva, 2016) outlined the following elements of the process:

a. Fixing the objective;

b. Defining the content and progressions;

c. Selecting the techniques and methods to be used;

d. Monitoring the acquisition procedure; and

e. Evaluating what has been acquired.

In the present study, writing autonomy is the ability of EFL majors to self-direct themselves while writing, to depend on themselves in learning writing within the designed website, to seek peer feedback, and to use certain writing strategies, namely generating ideas, planning, revising, and self-regulating their writing.

\section{Process-Genre Approach:}

"This approach allows students to study the relationship between purpose and form for a particular genre as they use the recursive processes of prewriting, drafting, revision, and editing. It develops students' awareness of different text types and of the composing process. The different activities included in this approach ensure that grammatical and vocabulary items are taught not in isolation, but in meaningful, interactive situations and derived from the particular genre" (Badger and White, 2000).According to Badger and White (2000), the teaching procedure for the PGA is divided into the following six steps: (1) preparation, (2) modeling, (3) planning, (4) joint constructing, (5) independent constructing, and (6) revising. Figure (2) illustrates how these six steps interact in a recursive way with themselves and with other writing skills.

In this study, PGA is an approach that views writing as a reciprocal hybrid of both writing processes and genres not as different but as complementary perspectives. Its aim is to nurture the genres of writing through which the authority of learning is scaffolded gradually, through genre analysis, from the teacher to the students. At this point, the students begin to adopt the processes of writing until the final written products. 


\section{Web-Mediated Instruction:}

Olaniran, Rodriguez and Williams (2010) define WBI as e-learning that is a form of teaching involving the delivery of learning and curriculum materials via the Internet to individuals in remote places.

In the present study, WBI is an asynchronous web-based communication which is represented in a designed website through which the stages of PGA are involved in each session. The flexibility and motivation were concerned in this designed website. Having access to this webmediated PGA-based program, EFL majors are encountered to do meaningful tasks that address the target EFL writing skills.

\section{Review of Literature}

Affective factors should be considered to maintain positive writing development. Both of them should also be oriented towards involving EFL learners in meaningful writing tasks by which students are interested in writing inside EFL class or beyond. Consequently, EFL learners can actively participate in the learning process as the paradigm of student-centered instruction and life-long learning have been actually confirmed in EFL-writing instruction. Promoting Learner autonomy in the EFL class, in general, and in the writing class, in particular, can maintain student-centered tasks and the active engagement of EFL learners.

\section{Learner Autonomy: Definition and Key}

\section{Features}

Boyadzhieva, (2016) defined learner autonomy as "a self-directed process of learning. $\mathrm{He}$ outlined the following elements of this process:

a. Fixing the objective,

b. Defining the content and progressions,

c. Selecting the techniques and methods to be used,

d. Monitoring the acquisition procedure, and

e. Evaluating what has been acquired" (p. 22).

Keeping the above elements in view, an autonomous learner should be able to set up goals for himself/herself, develop his/her strategies to cope with the new or unforeseen learning situations, assess his/her weakness and strengths at work, and learn from his/her success and failures to be more efficient learner in the future. Considering the proper utilization of autonomy as a term for learning, Thanasoulas (2000) stated that autonomy can be used

1. for situations in which learners' study entirely on their own,

2. for a set of skills which can be learned and applied in self-directed learning,

3. for an inborn capacity,

4. for the exercise of learners' responsibility for their own learning, and 
5. for the right of learners to determine the direction of their own learning (p.15).

Underlying what Thanasoulas stated of the usage of autonomy in learning, instruction should focus on learning rather than teaching. Focusing on the learning process, teachers can seek to engage and activate the learners' abilities in constructing knowledge on their own. By the way, the intended learning outcome could be facilitated by the teacher and attained autonomously by the learner.

However, learner autonomy may be not an inborn capacity as Thanasoulas stated above. In this context, both Reinders and Balcikanli (2010) assured that autonomy could not be naturally developed. Thus, they examined to what extent EFL teacher training courses prepare teachers for fostering autonomy. The authors found that EFL teacher education programs included almost no information about learner autonomy at all and did not, with one or two minor exceptions focus on the development of skills for supporting autonomous learning.

Simply put, learning autonomy is closely related to teacher autonomy. Once student teachers are trained to have their own ways of constructing knowledge, to participate in goalssetting, to take their own reflections into account, and to let them engage independently so that their roles in learning are manifested, they can appreciate the vivid value of fostering learner autonomy in their future classrooms. In this vein, Louis (2006) holds upon the point that teachers should encourage learners to work independently helping them know how to make decisions about their learning process because directing and participating their learning process actively can help students develop awareness of the responsibilities that they should fulfill during the process.

In this way, students may work confidentially outside the classroom without getting help from the teacher. That is, teachers should not transfer knowledge to students. Instead, they should teach them 'learning to learn'. Hence, "the autonomous learner is not one to whom things merely happen; he is one who, by his own volition, causes things to happen. Learning is seen as the result of his own self-initiated interaction with the world" (Thanasoulas 2000:12). Accordingly, learning can be for its own sake, not as a compulsory duty that must be done in a specific setting with rigid rules. Rather, learning can be lifelong that can be applied to different aspects of life and it could be a renewable experience either.

\section{Theoretical Bases of Learner Autonomy:}

Learner autonomy as an affective construct of learning is based on humanism and constructivism premises. Humanists emphasize the importance of self-concept and emotional factors in learners' learning process, paying 
more attention to "learning", and emphasizing that learners are the subjects of information processing and the active builders of learning, rather than passive information recipients and indoctrinated objects. Constructivists think that learners should get their knowledge not through what has been taught by teachers, but through their own active learning, exploring, discovering, and constructing and they use the necessary learning materials through the method of constructing meaning (Little, 2006). Yeung (2016) advocated the constructivist perspective of learner autonomy and stated that it provides learners with plenty of discourse initiatives that conventional pedagogies do not offer. Initiatives such as asking exploratory questions, making suggestions, challenging others' statements, and evaluating learning plans, tasks, and outcomes become important from this analytical angle.

Putting these theoretical bases into practice to an EFL classroom environment, EFL teachers should provide students with authentic experiences of teaching that draw upon learners' real-life situations. Hence, EFL teaching could be humanized and the learner can be eager to process information that is beneficial to his/her own life. With respect to constructivists, EFL teachers should design vivid learning experiences that adhere to the active participation of learners.
Moreover, learner autonomy does not mean the absence of guidance. Rather, it is the outcome of a learning process that provides the learners with the opportunity to work with such guidance as they wish to take, whether from peers, electronic media, or teachers. This view was claimed by Jing (2006) who argued that "learner autonomy as a process concerned with the negotiation between teacher and learner in an atmosphere of genuine dialogue and collegiality" (p.3). When teachers engage their students in group work activities, discussion forums, or peer feedback support, they give them the opportunity to learn from one another. This, in turn, gradually moves them from depending on their teachers, as the only source of knowledge transmitter, to depending on peer support. Then, a gradual shift towards complete autonomy of learning may be attained thereof.

\section{The Potential of Fostering Autonomy in EFL Writing:}

As mentioned before, EFL writing is a complex skill which necessitates more efforts to be learned than other language skills. Learning writing could be inadequate if only rely on the two or four hours learning in the classroom. Teaching writing requires more time, more effort, as well as more guidance. Thus, the demand for autonomous learning in writing is a crucial issue that should be focused on. In other words, students should be given an extended 
amount of time to generate ideas, plan, write, rewrite, and revise. Thus, autonomous learning with all its aspects should be actually implemented in the EFL writing class. Autonomy and writing are closely interrelated with one another.

Drawing from the literature, there is a close relation between EFL learner autonomy and the writing process. In this regard, Hyland (2006) asserted that learner autonomy in the area of writing could be conceptualized as the possession of autonomous attitudes, which refer to the willingness to take charge of one's learning of writing and the self-confidence and motivation to do so, and autonomous skills, which is manifested through the use of strategies in writing and learning to write. Moreover, King (2008) found out that the process approach of writing is one of the crucial approaches of teaching writing that holds the greatest potential in fostering learner autonomy because of its emphasis on self-discovery and reflectivity during the writing process.

Practically, an autonomous learner of writing should be able to use such learning strategies as goal setting, planning for writing, making decisions on what and how to learn, selfmonitoring, and self-assessment. Affectively, he or she feels in control of his or her own writing, feels the need to take charge of his or her own learning by setting learning goals, choosing appropriate learning strategies and evaluating his or her own learning progress (Lavasani, 2008; Bazrafkan \& Bagheri, 2014). An autonomous learner of writing thus needs to have cognitive, meta cognitive, and affective skills, knowing what to learn as well as how best to learn. For example, an autonomous writer could seek feedback from his/her teacher or his/her peers, reflect on his/her own writing and use rubrics and self-checklists for revising and editing.

Since independence from the teacher is the first step towards learner autonomy in writing and more intrinsic types of motivation are necessary for later development, the fostering of these two attributes should be important goals in curriculum design and teaching Practices in EFL writing. This view has been advocated by Yeung (2016) who proposed that teacher independence is one of the attitudinal aspects of learner autonomy. She found out that a degree of independence from the teacher may possibly be a prerequisite for autonomy development in terms of writing skills, while motivation may have a more important role to play in its subsequent development.

It is obvious that for EFL learners, writing is a means of recording and reformulating knowledge and developing ideas. It may also be a means of personal discovery, creating, and self-expression. Additionally, Al-Hazmi (2006) 
persuasively states that writing is an essential ingredient in critical thinking instruction since it promotes greater self-reflection and taking broader perspectives than does oral expression. Suitably written assignments, she believes, can stimulate classroom writers to enhance their active learning spontaneously. Writing is, by nature, a self-critical one. It lends itself to the kind of introspection that would prompt students to reflect on their understanding, and to communicate their feelings about what they know, what they are doing, what they are struggling with, and how they are experiencing their learning.

This is compatible with the required fundamentals for developing autonomy as suggested by Little (2006) that learner involvement, learner reflection, and appropriate target language use. The first principle learner involvement refers to affective and meta cognitive aspects of language learning, encouraging learners to be involved actively in their learning process. Learner reflection is associated with the meta cognitive aspect of language learning: learners should be encouraged to become critical thinkers to develop awareness about the learning process and content. Lastly, appropriate language use is related to the communicative and the meta cognitive aspects, proposing that students should use the target language both for communicative purposes and meta cognitive activities such as planning, monitoring, evaluating...etc.

Giving rise to feedback as a requisite component in the process approach, Kunschak (2007) promoted scaffolded feedback (SF) in the writing process as a valuable tool by which learner autonomy could be developed. Within $\mathrm{SF}$, there is a gradual shift of written corrections from the teacher to the learner. Since the teacher is accessible in editing margins, learners are forced to prefer teacher comments which make learner autonomy compatible with lifelong learning.

Different forms of feedback are helpful in the writing process. In order to move them in the direction of autonomy, which in the case of writing classes would be the capacity for selfediting, students need to be guided in a scaffolded way. Similarly, Moussaou (2012) proved that peer evaluation in a writing classroom is one of the most effective techniques that help foster student writers' autonomy. Accordingly, being autonomous and self-directed does not necessarily mean learning alone and discarding peer support. There is an implicit collaborative element in autonomous learning since learners have to interact, negotiate, and collaborate with peers. Learner autonomy does not mean the absence of guidance. It is rather the outcome of a learning process that provides the learners with the 
opportunity to work with such guidance as they wish to take it even if it is from peers.

In the present study, feedback is manifested in different ways within the suggested webmediated PGA based program. Feedback Page represents the first form through which each student should have his/her feedback page. At student feedback page, revised written genres will be uploaded by the teacher to each one. So, it is an expert feedback or scaffolded feedback. The second form of feedback is peer feedback which will be represented in peer comments at both discussion forums and publishing page. In this way, students become intrinsically motivated to write not just to the exam. Feedback forms can notably empower the thirdyear EFL majors by which they can feel in control of their writing. Self-checklists and selfediting code tables are utilized effectively in the suggested program through which students could respond to them easily and positively. In this regard, Kulsirisawad (2012) stated that learners become less dependent on the teacher by learning to collaborate with their peers. So, he recommended peer feedback as a pedagogical practice designed to build up students' academic writing competencies and help student writers become less dependent on the teacher.

\section{Some factors concerned in Writing}

\section{Learner Autonomy:}

For fulfilling the highest degree of positive outcomes companied writing autonomously, there are some influential factors that should be taken into account. Blidi (2017) determined some of them as follows:

\section{a. Voluntariness:}

This implies that if students are compelled to join a self-directed learning program, they may not benefit as much as those who volunteer. This refers to the element of compulsion with regard to the development of learner autonomy often seen as counterproductive. Compulsion contradicts with the principles of readiness and willingness that are influential in the learner autonomy development process. Benson (2001) argued that "... the more successful curriculumbased approaches to autonomy do not simply leave students to 'sink and swim'. Invariably, their effectiveness depends upon implicit or explicit scaffolding structures that support learners in decision-making process." (p.24).

For this research, the features in the scaffolding process include:

- Selecting topics related to real-world tasks

- Modeling genre requirements

- Managing feedback from peers and tutor

- Critical self-evaluation at every step

- Searching for and managing secondary research materials 
- Checking of work against marking descriptors

- Focusing on language, content, and style

\section{b. Learner Choice of Learning Tasks:}

Perceiving learner autonomy as an exercise in learning that involves making decisions. Decisions on learning include setting objectives, defining contents and progressions, selecting methods, monitoring the procedure and evaluating the outcome of learning.

\section{c. Flexibility:}

Flexibility means that students can change learning options, such as objectives, contents, process of learning, among others, according to their needs and interests. This is in line with learners' need to identify the learning opportunities availed for them. The relationship that the teacher establishes with students, supporting and guiding them in their learning, plays a crucial role in fostering autonomy. Accordingly, teacher's role is to help learners develop the readiness and willingness to become autonomous and to embrace a supportive role as a facilitator who helps learners formulate their goals more clearly and provides feedback, encouragement, and reinforcement.

In the same vein, Begum and Chowdhury (2016) reached to a consensus of the factors that affect learner autonomy in EFL learning which included the different learning strategies and learning styles, the learners' attitude, self-esteem and self-confidence, and the practice of using technology and library resources. In the field of virtual education, the concept of autonomy has gained a very important place.

\section{Web-Mediated PG- based Program for \\ Fostering Writing Autonomy:}

The development of web-mediated facilities in EFL instruction provides the practical means whereby learners can take a more active part in determining their own objectives and syllabi, as well as the path and timing they choose. Consequently, a change in the traditional roles could be brought out whereby the teacher was in tight control in the transmission of curricular content. It has also increased the teachers' capacity to facilitate the task of helping learners become more independent. In this context, the teacher's role becomes that of coordinator and provider of strategies, rather than simply content.

In comparison with the conventional paradigm of learning, web-based instruction has the following advantages. First, web-based learning can overcome the obstacles in the scope of time and space of traditional learning. Learners can learn at any time and at any place as long as the Internet is available at their convenience and waste less time in taking vehicles. Second, the Internet can make personalized learning come true. Without the limitation of learning time, learners can arrange their own learning schedule 
flexibly and select learning contents satisfying their personal goals. Third, the Internet also provides learners with convenient communication approaches. Such web-mediated communication tools as e-mail, blog, and web chat can stimulate learner's desire for using a foreign language to communicate with native speakers. Fourth, with the support of sufficient and varied forms of sources, the Internet enables learners to enjoy a wide range of learning materials such as video, sounds, vivid pictures...etc. (Lin-lin, 2015).

Research discussed the effect of web-mediated FL instruction on developing EFL learners' autonomy. For example, Hobrom (2004) evaluated the value of online resources as a learning aid for the autonomous language learner. The findings suggested that the participants perceived themselves as autonomous learners in two ways. One had to do with such characteristics as taking more responsibility, being more motivated...etc. The other was about them as learners such as improvement in their skills and being able to evaluate themselves.

Adopting constructivist base of learner autonomy, Jiemin (2009) argued that teacher support, constructivist pedagogy, and web-based learning environment can enhance the students' learner autonomy, and the student misconception of learner autonomy. Examining the effect of using Weblog on students' writing autonomy, Noordin and Hamzah (2013) demonstrated that weblog made learners experienced unlimited time and place, more independence and freedom in publishing and exchanging comments. With the empirical data presented in this study, the weblog can be applied as a suitable instructional tool to promote autonomy among language learners. Shen (2014) explored whether a web-based autonomous learning setting could improve the college students' overall English performance more effectively than the traditional English teaching setting. Findings showed that more than three-fourths of the participants in the experimental group were satisfied with the webbased autonomous learning setting.

Bedoya (2014) called for designing virtual EFL courses that promote autonomous learning. He claimed that factors such as course design, platform, and the teacher's role influenced the students' exercise of autonomy. Belabbas (2016) found out that autonomous learners can acquire new vocabulary faster if a model of teaching vocabulary learning strategies programmed is supplied. Abdullah (2015) explored the development of learner autonomy abilities in writing via web-based asynchronous peer feedback (WAPF). The learner autonomy abilities that emerged from this study were reflection, decision-making, and revision. 
Findings revealed that the respondents were able to develop their autonomy abilities in writing through the WAPF. Ultimately, the respondents were able to reflect, decide, and revise better in their writing.

Advocating web-based autonomous learning, knowledge could not be restricted to one source. Instead, it is multi-sources by which the emphasis is then shifted from just acquiring knowledge to reflecting upon it and taking control of choosing the most appropriate amount of it. Having access to the suggested webmediated PG based- program that utilized in the present study, each student could actively participate in interacting with each stage of PG according to his/her own time of starting as teaching had the form of asynchronous communication. One issue of writing is being proposed; however, each member reflects upon it differently.

Some influential factors in developing learner autonomy can be embraced in the present study. For example, there is a sort of flexibility from the teacher in asking students to move from one stage of PGA to another recursively; one begins with modeling stage, then returns to preparation stage, and makes a quick shift in the planning stage, then returns again to the modeling stage to verify from some basics of writing the target genre. One student finishes one session in a day; another one takes two days to finish.

\section{Design of the study}

The two-group post-assessment design was utilized in the experiment. The participants were randomly assigned to either an experimental group or a control group.

\section{Participants of the study}

The participants of the present research consisted of third year EFL majors enrolled in Sohag Faculty of Education during the academic year 2017/2018. They were $(\mathrm{N}=23)$ for the experimental group and $(\mathrm{N}=23)$ for the control group.

\section{Delimitations of the Study}

The present study has been restricted to the following delimits:

1. The subjects of the present study are the third-year English majors at Sohag Faculty of Education where the researchers work. This stage of EFL majors was chosen because of the following considerations:

a. This stage of third-year EFL majors at Sohag Faculty of Education was chosen because it represents the transitional stage between the EFL freshmen and EFL graduates who should have thorough knowledge in writing different genres of writing.

b. Those are the future EFL teachers whose well-preparedness is a long-run 
investment in the future of their EFL students. Unless they have a thorough command of EFL writing skills, they are not likely to transfer the basics of writing process either in literary or nonliterary genres to their students.

c. Through teaching them, the researchers found out that they have poor writing skills especially in functional writing genres that are required in their future workplace either in content skills or organization skills.

2. Depending on the results of Needs Assessment of Student Writing (NASW) (see Appendix B), three written genres are required in the present study, as follows:

- The narrative genre (first person);

- The functional genre; and

- The expository genre.

\section{Instruments and materials of the study}

To achieve the objective of study, the researchers constructed the following instruments and materials:

1. A writing autonomy scale.

2. A suggested web-mediated process-genre based program test.

\section{Findings of the Study}

T-test formula for independent samples was employed in testing the hypothesis of the study as follows:

\section{Question One}

Data was represented in Table (9) above revealed that there was a statistically high significant difference at (0.01) level between mean scores of the experimental group students and the control group students on each dimension considered in the writing autonomy scale in favor of the experimental group students. Thus, the hypothesis two was accepted. As the experimental group students share the control group ones all variables except the treatment variable, their significant responses in the post-testing could be attributed to the effect of the suggested WMPGP. Hence, the WMPGP for writing instruction resulted in developing autonomous aspects in writing compared to the underlying traditional approach for teaching writing.

\section{Question Two}

The theoretical framework of the study tackled the major features of the suggested of WMPGbased program.

\section{Discussion}

The results revealed that the experimental group students' ability to be autonomous learners before, during or post writing has been 
improved in the current study as compared with their peers in the control group.

Analyzing the third-year EFL majors' responses for each dimension in the writing autonomy scale, it was surprisingly found that they began to follow most of the autonomous aspects of writing ; taking control of their own learning for writing, going independently from one stage to another within PGA stages, utilizing effectively both of direct writing strategies and meta-direct writing strategies, communicating asynchronously with their teacher within the WMPG- based program so that the decision upon appropriate time and place for interaction was shared between them and their teacher, and go recursively among the PGA stages as the flexibility of web-based instruction and PGA stages have been promoted within the suggested program.

The results of the current study are consistent with the results of Hyland (2006) who asserted in his conducted study that learners' autonomy in the area of writing could be conceptualized as the possession of autonomous attitudes, which refer to the willingness to take charge of one's learning of writing and the self-confidence and motivation to do so, and autonomous skills, which is manifested through the use of strategies in writing and learning to write. Moreover, King (2008) found that the process approach of writing is one of the crucial approach of teaching writing that holds the greatest potential in fostering learner autonomy because of its emphasis on self-discovery and reflectivity during the writing process. Giving rise to feedback as a requisite component in the process approach, Kunschak (2007) promoted scaffolded feedback (henceforth SF) in the writing process as a valuable tool by which learner autonomy could be developed. Within $\mathrm{SF}$, there is a gradual shift of written corrections from the teacher to the learner. Still the teacher is accessible in editing margins; learners are forced to prefer teacher comments which makes learner autonomy is compatible with lifelong learning. Different forms of feedback are helpful in the writing process. In order to move them into the direction of autonomy, which in the case of writing classes would be the capacity for selfediting, students need to be guided in a scaffolded way. Similarly, Moussaou (2012) proved in his study that peer evaluation in a writing classroom is one of the most effective techniques that help foster student writers' autonomy.

What has been provided of asynchronous writing tasks and web-facilities within the suggested WMPGP based-program in the current study contributed to a great extent to develop the third-year EFL majors' autonomy in writing. This was achieved through certain aspects. The first aspect was manifested in the 
promotion of student-centered paradigm instead of teacher-centered one. Besides, one of the utmost importance in learner-centered instruction is being aware of the ability of learners to take their own control of learning, self-regulate, reflect, and be motivated. All these attributes of learner-centered instruction constitute the construct of learner autonomy. Having designed writing tasks in the suggested program that addressed direct writing strategies; generating ideas, modeling, reflecting, selfrevising, and planning, the participants' ability to think, reflect, decide upon the proper time to begin or end the task was highly maximized.

Within the designed WMPG-based program, students could learn at any time and place as long as internet is available at their convenience and waste less time in taking vehicles. Without the limitation of learning time, students could arrange their own learning schedule flexibly and select the written genres that satisfy their personal goals (see Needs Assessment of Student Writing, Appendix C).With the support of sufficient and varied forms of sources, the designed website enabled students to enjoy a wide range of writing materials such as relevant videos, sounds, vivid pictures, power point shows.

Another aspect of the suggested program that contributed in the development of learner autonomy in writing is the availability of feedback with its two kinds; immediate feedback in the discussion forums and the delayed one in the(Feedback Page) which was provided for each student. In the same vein, Moussaou (2012) proved in his study that peer evaluation in a writing classroom is one of the most effective techniques that help foster student writers' autonomy. Similarly, Kunschak (2007) promoted scaffolded feedback (henceforth SF) in the writing process as a valuable tool by which a learner's autonomy could be developed.

\section{Conclusion}

Web-mediated PGA sessions assisted in the development of learner autonomy abilities in writing among the respondents. Along the asynchronous sessions, the participants played significant roles: establishing e-learning community, monitoring, motivating and scaffolding. During the writing experience, the respondents had developed their learner autonomy abilities in reflecting, decision making and revising of their essays. Clearly, this study has proven that the dire need for autonomous learner-centered learning for this country can be resolved through this type of learning process.

\section{Suggestions for Further Research}

1. The present study suggested how WMPGP could promote students ${ }^{\text {ee }}$ writing autonomy. 
More studies are required to examine how web-based instruction can affect students ${ }^{\text {ee }}$ writing performance, writing process and engagement.

2. Moreover, in this study, students ${ }^{\text {ee }}$ writing autonomy was investigated. Further study might investigate the effect of WMPGP on the development of autonomy in other skills.

\section{References}

Abdallah, M. S. (2011). Web-based new literacies and EFL curriculum design in teacher education: A design study for expanding EFL student teachers' language-related literacy practices in an Egyptian pre-service teacher education programme. (Unpublished Doctoral Dissertation).University of Exeter. College of Social Sciences and International Studies, UK, London.

Ahmad, N., Yaakub, R. \& Megat Abdul Rahim, P. R. (2004). Towards learner autonomy in teaching English in Malaysia. A conference paper presented at the 4th International Symposium on ELT in China, Beijing (21-25 May 2004).

Badger, R. \& White, G. (2000). A process genre approach to teaching writing. ELT Journal, 54(2), 153-160

Bagheri, M \& Aeen, L (2011).The Impact of Practicing Autonomy on the Writing Proficiency of Iranian Intermediate EFL Learners. Journal of

Pan-Pacific Association of Applied Linguistics, $15(1), 1-13$.

Balcikanli, C. (2010). Learner autonomy in language learning: Student teachers' beliefs. Australian Journal of Teacher Education, 35(1), 90-114.

Bazrafkan, N \& Bagheri, M (2015).The relationship between critical thinking, autonomy and writing skill of the Iranian EFL learners. International Journal of Language Learning and Applied Linguistics World (IJLLALW), 7 (3), 379-392.

Belkhir, A \& Benyelles, R (2017). Identifying EFL learners essay writing difficulties and sources.International Journal of Learning, Teaching and Educational Research, 16 (6), 8088.

Benson, P. (2006). Autonomy in language teaching and learning. United Kingdom: Cambridge Univ. Press.

Benson, P. (2009). Making sense of autonomy in language learning. In S. Toogood, R. Pemberton \& A. Barfield (Eds.), Maintaining control: Autonomy and language learning (pp. 13-26). Hong Kong: Hong Kong University Press.

Boyadzhieva, E, (2016). Learner-centered Teaching and Learner Autonomy. Procedia, 232 (12), 35-40. 
Carr, C., L. (2013). Enhancing EAP students' autonomy by accommodating various learning styles in the second language writing Classroom.ITJ, 10(1), 39-52.

Chiu, H. L. W. (2012). Supporting the development of autonomous learning skills in reading and writing in an independent language learning center. Studies in Self-Access Learning Journal, 3(3), 266-290.

Foroutan, M, Noordin, N \& bin Hamzah, M (2013). Weblog promotes ESL learners' writing autonomy. Journal of Language Teaching and Research, 4 (5), 994-1002.

Fuchs, C, Hauck, M \& Müller-Hartmann, A (2012). Promoting learner autonomy through multiliteracy skills in cross-institutional exchanges. Language Learning \& Technology, 16 (3), 82-102

Hadi, K. (2012). Promoting learner autonomy in an EFL context: Reader Readiness.

Hasim, Z; Lumpur, K \& Zakaria, A (2016). ESL Teachers' knowledge on learner autonomy. Taylor \& Francis Group, https://umexpert.um.edu.my/file/publication/0000 $\underline{9863 \text { 146265.pdf }}$

Hyland, K. \& Hyland, F. (2006).Feedback on second language students' writing. Language Teaching. 39 (2): 83-101

Hyland, K. (2000). ESL writers and feedback, giving more autonomy to students. Language Teaching Research.4 (33).

Ikonen, (2013).Promotion of learner autonomy in the EFL classroom: The students' view Implications for Essay Writing Curriculum and Instruction. Available online at https://jyx.jyu.fi/dspace/bitstream/handle/123456 789/42630/URN:NBN:fi:jyu-

201312102771.pdf? sequence $=1$. Retrieved on 18, October,2013.

Kaur, R \& Sidhu, G (2010). Learner autonomy via Asynchronous Online Interactions: A Malaysia perspective. IJEDICT, 6(3), 88-100.

Kulsirisawad, P. (2012). Developing learner autonomy in EFL writing classrooms via peer feedback. Bangkok. CULI National Seminar 2012 Proceeding, 3, 68-76.

Little, D. (2004) "Democracy, discourse and learner autonomy in the foreign language classroom". Utbildning and Demokrati 13.3: $105-126$

Little, D. (2006). Learner autonomy: Drawing together the threads of self-assessment,goalsetting and reflection. Training teachers to use the European Language Portfolio.Retrieved from http://archive.ecml.at/mtp2/Elp_tt/Results/DM_la yout/00_10/06/06\%20Supplementary\%20text.pdf 
Louis, R. (2006). Helping Students Become Autonomous Learners: Can technology help?.Teaching English with Technology. A Journal for Teachers of English, 6(3) retrieved 04.03.2013 from http://www.iatefl.org.pl/ call/j_esp25.htm.

Masits, D. (2016). EFL students' ability in performing autonomous learning and their writing proficiency across cognitive styles.(Unpublished Master's thesis).University of Jyvaskyla,Finland, Europe.

Nguyen, V.L. (2016). Learner autonomy in Vietnam: Insights from English language teachers' beliefs and practices. In: Barnard, R., Li, J. (Eds.), Language learner autonomy: Teachers' beliefs and practices in Asian contexts (pp. 1-22). Phnom Penh: IDP Education.

Olaniran, B. A., Rodriguez, N. B., \& Williams, I. M. (2010).Cross-Cultural Challenges in WebBased Instruction. Knowledge Management \& ELearning: An International Journal, (2) 4,448465.

Sakai, S., Takagi, A., \& Chu, M.-P. (2010). Promoting learner autonomy: Student perceptions of responsibilities in a language classroom in East Asia. Educational Perspectives, (43), 12-27.

Yan, G. (2007). Autonomous English learning among postgraduate EFL learners in China: A study of attitudes and behaviors. The Journal of Asia TEFL, 4(3), 47-70
Yeung, M. (2016).Exploring the construct of learner autonomy in Writing: the roles of motivation and the teacher.English Language Teaching,(9) 8,122-139.

Yeung, M. (2016).Exploring the construct of learner autonomy in Writing: the roles of motivation and the teacher. English Language Teaching,(9) 8,122-139.

Yuliani, A. (2017). Project -based learning in promoting learner autonomy in an EFL classroom. Indonesian Journal of Applied Linguistics, (7) 2, 45-55. 